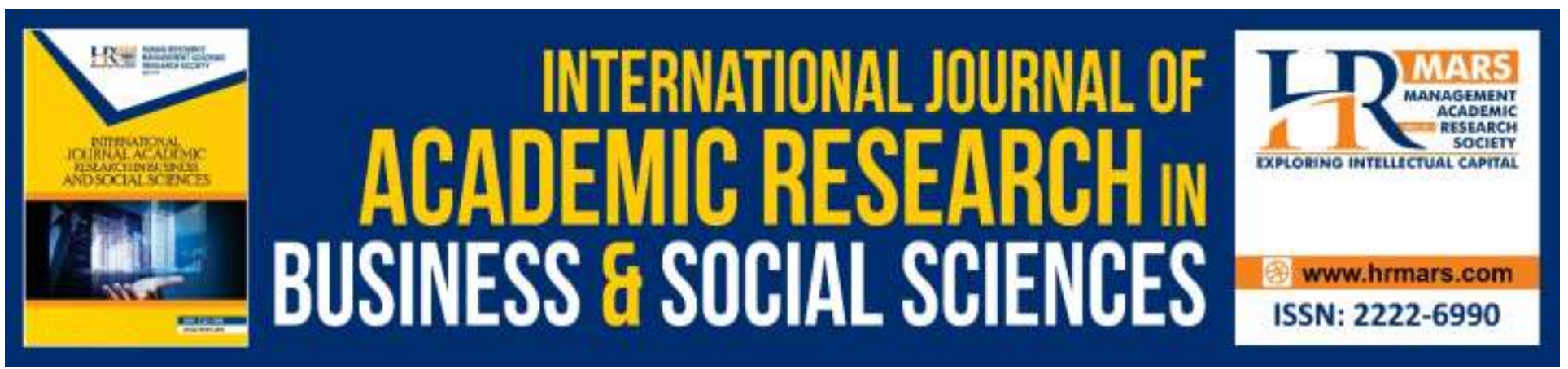

\title{
A Study on Critical Factors Affecting English Language Anxiety in Selected Schools
}

\author{
Noor Illi Binti Elas, Faizah Binti Abd Majid
}

To Link this Article: http://dx.doi.org/10.6007/IJARBSS/v9-i13/6259

DOI: 10.6007/IJARBSS/v9-i13/6259

Received: 19 March 2019, Revised: 17 April 2019, Accepted: 02 July 2019

Published Online: 20 August 2019

In-Text Citation: (Elas, Majid, \& Narasuman, 2019)

To Cite this Article: Elas, N. I. B., Majid, F. B. A., \& Narasuman, S. A. (2019). A Study on Critical Factors Affecting English Language Anxiety in Selected Schools. International Journal of Academic Research in Business and Social Sciences, 9(13), 251-261.

Copyright: (c) 2019 The Author(s)

Published by Human Resource Management Academic Research Society (www.hrmars.com)

This article is published under the Creative Commons Attribution (CC BY 4.0) license. Anyone may reproduce, distribute, translate and create derivative works of this article (for both commercial and non-commercial purposes), subject to full attribution to the original publication and authors. The full terms of this license may be seen

at: http://creativecommons.org/licences/by/4.0/legalcode

Special Issue: Revolutionizing Education: Challenges, Innovation, Collaboration, 2019, Pg. 251 - 261

http://hrmars.com/index.php/pages/detail/IJARBSS

JOURNAL HOMEPAGE

Full Terms \& Conditions of access and use can be found at http://hrmars.com/index.php/pages/detail/publication-ethics 


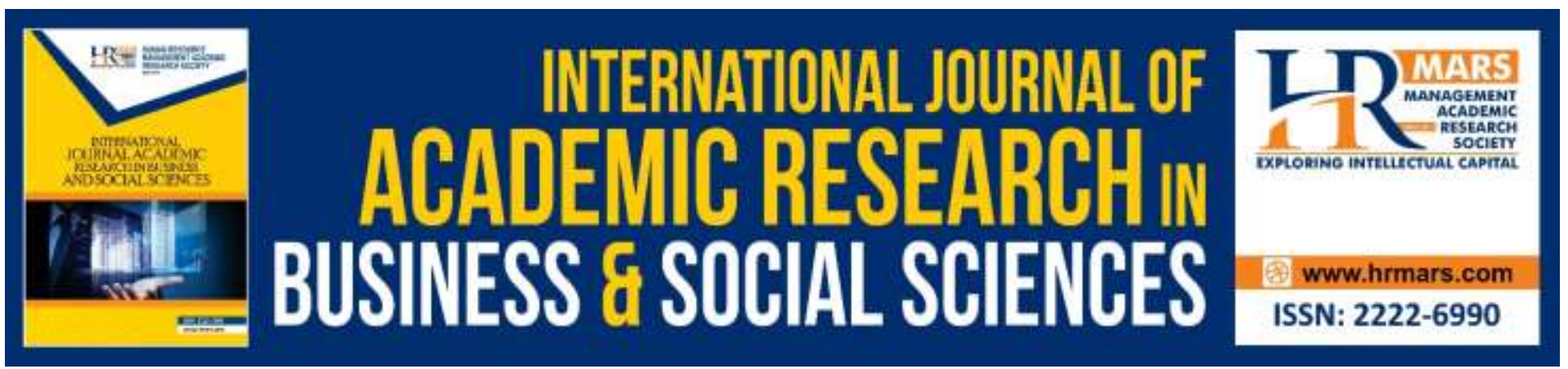

\title{
A Study on Critical Factors Affecting English Language Anxiety in Selected Schools
}

\author{
Noor Illi Binti Elas, Faizah Binti Abd Majid, Suthagar A/l \\ Narasuman \\ Faculty of Education, Universiti Teknologi MARA, UiTM Puncak Alam Campus, 42300 Puncak Alam, \\ Selangor, Malaysia. \\ Email: elas1963@yahoo.com
}

\begin{abstract}
This paper discussed a study proposed to analyse the critical factors affecting English language anxiety among upper secondary students in selected schools in Malaysia. In countries where English is taught formally as second language, learners faced different levels of anxiety and by individually they had developed specific types of anxiety in learning the English Language. Also, where English was taught as formal school subject, school climate was considered as one of the variables that affects English Language anxiety. Another factor with regards to rapid globalization and modernization was teacher's competency in utilizing technological tools which was also a concern that affects English Language Anxiety. The objective of the research was to study the relationship between school climate and Technology, Pedagogy, and Content Knowledge (TPACK) in affecting English Language Anxiety. An amount of 315 student participants will answer an adapted questionnaire known as the English Language Classroom Anxiety Scale (ELCAS) and a self-developed questionnaire known as School Climate English Language Anxiety (SCELA). Meanwhile, the English Language teachers involved in the study will answer an adopted questionnaire Technology Pedagogical Content Knowledge (TPACK). The data obtained from all three questionnaires will be presented in the form of descriptive statistics and will be analysed using the Statistical Package for Social Science (SPSS) software version 22.
\end{abstract}

Keywords: English Language Anxiety, Technology Pedagogical Content Knowledge, English Language Classroom Anxiety Scale, School Climate English Language Anxiety.

\section{Introduction}

Education has always been an integral part of Malaysian culture and society. However, Lim Soh Lan (1994) argued that English is not the language that is used by most communities in Malaysia because they prefer their native language. In line with this, Brown (2007) stated that learning a second language is a complex task and the course of language learning is the core subject for second 
language learners. Therefore, in tandem with previous sentence, English as a second language language learners' need to be well equipped with the core language skills such as reading, speaking, listening and writing along with basic grammar in order to be proficient language users. This is because, in order to accomplish the aim, learners need to participate actively in the classroom while remaining positive throughout the learning process. Thus, along with proper clarification and instructions in the classroom they may be more engaged in the learning activities that would help them to enhance their second language skills.

However, Alkhasawneh (2016) stated that students who need to master the English Language might encountered difficulties during this process. This insight leads to abundant researches focusing on teachers and students in SLA (Second Language Acquisition) and their relationship to affective factors such as motivation and attitudes which need to be considered as well in language learning outcomes. Parallel with this point, Cui (2011) states that anxiety is a crucial affective factor that been studied since the 1970s. Anxiety literally could mean that there are distress and hesitation in thought and feelings. This was supported by Alrabai (2014) who stressed that anxiety was a phenomenon that relates to the feeling of discomfort, nervousness, vague fear and apprehension which was unrelated to a certain situation. Thus, anxiety when is associated with language, it is known as language anxiety and when it occurs in the environment of learning English as a second language, it is addressed as English Language Anxiety (ELA).

English Language Anxiety (ELA) has been the main focus in many studies due to its impact on English Language Learning. In Malaysia, Nur Afiqah (2015), states that despite learning English for more than 10 years, Malaysians still encounter challenges in using the language efficiently. Accordingly, Horwitz, Horwitz \& Cope (1986) English as a second language learners often feel stressed, nervous and anxious while learning the language. Most of them face a "mental block" during the language learning process. This situation can happen to both beginners and advanced learners (Nur Afiqah, 2015) even though they are proficient in the English Language despite of the complex learning process. However, for some learners the complexity of the process becomes acute when anxiety sets in.

As this case was dug deeper, hence, according to Aydin \& Zengin (2008), the level of anxiety needs to be measured as it can raise the awareness of the sources affecting language anxiety and ways to overcome it in the language learning process. The level of anxiety has a debilitative or facilitative effect, depending on how learners perceive it. Facilitating anxiety, as the name suggests, is believed to be a type of anxiety that improves learning and performance (Hamid \& Baldauf JR, 2013) meanwhile debilitating anxiety is known as negative anxiety which affects learners through worry and self-doubt and indirectly reduces participation in language learning (Oxford, 1999). Hence, to support this point, Jamilah (2017) highlighted that high level of anxiety was correlated with poor performance in language learning.

It is clear that anxiety, attitude and motivation play an important role in second language learning. With this as a key point, affective factors such of self-perception, beliefs, feelings, and behaviors which related to language learning depends on the essence of the language learning process (Yvonne \& Gurnam, 2013). These affective factors in language learning are the cause to three types of English Language Anxiety that had been stated repeatedly in numerous researches. Therefore, as highlighted by the pioneer researcher on language anxiety, Horwitz, Horwitz \& Cope (1986) state that there are indeed three types of language anxiety that takes place in language 
INTERNATIONAL JOURNAL OF ACADEMIC RESEARCH IN BUSINESS AND SOCIAL SCIENCES

Vol. 9, No. 13, Special Issue: Revolutionizing Education: Challenges, Innovation, Collaboration., 2019, E-ISSN: 2222-6990 @ 2019 HRMARS

learning process which are Communication Apprehension (CA), Fear of Negative Evaluation (FNE) and Test Anxiety (TA). The explanations of these types of anxiety are as below:

- Communication Apprehension (CA)

Anxiety that happens because of the learner's incompetence or inability to express their thoughts and ideas. This impedes participation in conversations or communication with others.

- Fear of Negative Evaluation (FNE)

This relates to the student's need to make an impressive and positive social impression on others. They will try to avoid demonstrations of incompetence in evaluative situations.

- $\quad$ Test Anxiety (TA)

It is a type of apprehension related to academic evaluation such as fear of failing the test and engaging in certain evaluative situations.

As a matter of fact, English is a global language taught all over the world (Selami Aydin et al., 2016). In formal situations the learning takes place in a classroom within the environment and culture of a school or institution. Thus, the climate of the school plays an important role in learning the English Language. School climate is about the existing atmosphere in the school which is mainly governed by administrators and their leadership styles affects the way students and teachers accustom to their school hence affecting their attitudes and values towards school and work. This is supported by Mary, Catherine \& Philip (2010) who define school climate as a shared belief among teachers, students and administrators. Anxiety in English Language Learning is a psychological effect (Horwitz \& Cope, 1986) therefore, a positive school climate plays a vital role in language learning. Thus, a positive school climate can yield positive educational and psychological outcome $s$ for the school and its students as well (Kuperminc, Leadbetter \& Blatt, 2001). This is supported by Frenzel, Pekrun \& Goetz (2007) who suggested that learning environment will influence students' academicrelated achievement and is also related to their emotional experiences. Hence, school climate is a variable that could affect anxiety in language learning including second language learning. To be precise, school climate as proposed by Alexandra (2007) consists of three dimensions that need to be considered; Physical Dimensions, Social Dimensions and Academic Dimensions. The description for these three dimensions are as follow:

- Physical Dimensions:

- Appearance of the school building and its classrooms.

- School size and ration of the students to teachers on the classroom.

- Order and organization of classrooms in the school.

- Availability of resources.

- Safety and comfort

- Social Dimensions:

- Quality of interpersonal relationships between and among students, teachers and staff.

- Equitable and fair treatment of students by teachers and staff.

- Degree of competition and social comparison between students. 
INTERNATIONAL JOURNAL OF ACADEMIC RESEARCH IN BUSINESS AND SOCIAL SCIENCES

Vol. 9, No. 13, Special Issue: Revolutionizing Education: Challenges, Innovation, Collaboration., 2019, E-ISSN: 2222-6990 @ 2019 HRMARS

- Degree to which students, teachers, and staff contribute to decision-making at the school.

- Academic Dimensions :

- Quality of Instruction.

- Teacher expectations for student achievement.

- Monitoring student progress and promptly reporting results to students and parents.

Under these circumstances and considering the effect of school climate on anxiety, teaching ESL is indeed a challenging task. This is supported by Sneza, Biljana \& Dragana (2012) who stated that teaching ESL is a complex process because it associates with different variables concerning the teacher's roles. Hence, teachers play an important role in the language learning process, depending on how they apply their methods. This in reality correlates to teaching methodology in teaching English Language.

Since computer and instructional technologies have become a crucial factor in our lives by affecting learning and communication (Sahin, 2011), teachers need to equip themselves with practical knowledge on pedagogy, technology and their content areas. Notably, when teachers incorporate technology into instruction, students will be more interested to participate in the learning session (Schrum et al., 2007). With regards to the present discussion on school climate and anxiety, if a teacher is unable to combine technological tools to enhance the teaching of the English Language, this could be one of the factors affecting English Language Anxiety. This is because, Zucker et al., (2008) believes that technology can improve students' learning and support their learning as well. Therefore, this scenario need an approach that fits the teaching methodology and the best approach to fulfill this purpose is known as TPACK. The TPACK model proposed by Koehler and Mishra (2008) consist of Content Knowledge (CK), Pedagogical Knowledge (PK) and Technological Knowledge (TK). Then, these three basic forms of knowledge have overlapping parts namely: Pedagogical Content Knowledge (PCK), Technological Content Knowledge (TCK), Technological Pedagogical Knowledge (TPK) and finally at the intersection of the three components is TPACK as shown in Figure 1 below.

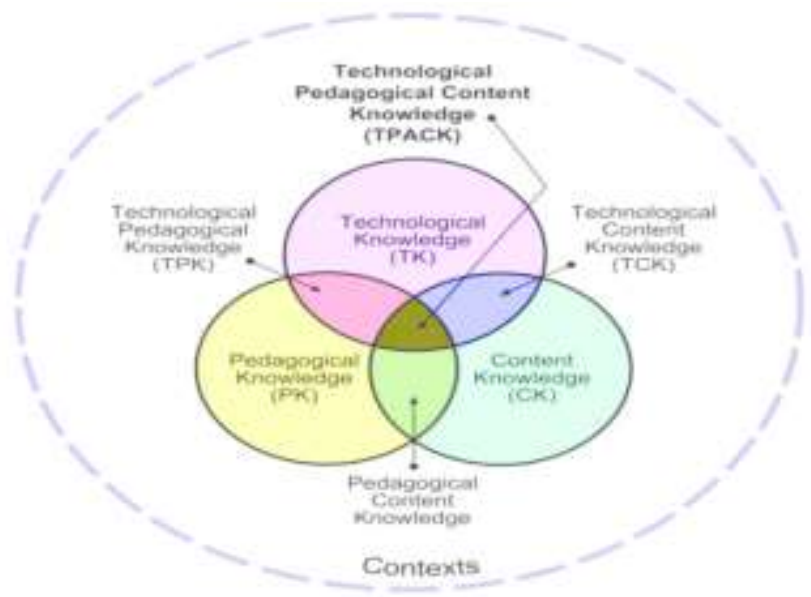

Figure 1: The Components of TPACK Framework (Graphic from TPCK - Technological Pedagogical Content Knowledge, 2010) 


\section{Background and Rationale}

Snezana, Biljana \& Dragana (2012) state that second language is like any other language which centres on material that must be understood by learners or even to be memorized for examination's sake, to please the language teacher, to make the parents proud and happy, to fulfil an inner desire and other feelings such as pride. This state of mind is a rife situation for language anxiety to set in. This is supported by Toth (2011) who states that anxiety provokes the potential for learning and has been a subject matter in second language research.

To begin with, language learners face problems such as anxiety most of the times (Hussein, 2010). In view of that, language anxiety is merged with a number of negative outcomes which can be classified as physical, psychological or social (Yazdanpanah, Sahragard \& Rahimi, 2010; Yarahmadi, 2011; Uzun, 2012). This is where the three types of anxiety as mentioned by Horwitz, Horwitz \& Cope (1986) play the role in language learning. Hence, in Malaysian education context, it is best to study which one of these anxiety types dominates influence on English Language Learning in schools.

Furthermore, anxiety has been negatively affecting language learning and found to be one of the frequent variables in psychology and education (Horwitz, 2001). Thus, it is best to measure the level of anxiety that takes place among second language learners in Malaysia. This is supported by Ilahi, Faraz \& Habibullah (2015) who state that learners at all levels may experience high or low levels of anxiety in language learning. This highlights the fact that the level of anxiety can be facilitative or debilitative to the language learner. High levels of anxiety can influence the learning negatively while low levels of positive anxiety can facilitate the language learning. Therefore, in the Malaysian context, there is a need to study the level of anxiety faced by language learners in order to look for the remedies to reduce language anxiety at school level.

Going through researches about anxiety, there are a lot of subjective variables that need to be taken into account. Variables such as gender, motivation, age, levels and dominant types of anxiety have been focused on. Therefore, the environment of the classroom and school as well as the teaching methodology should be examined as well. Overall these variables are collectively known as school climate. Hoy, Tarter \& Kootkamp (1991) state that school climate is all about the quality of school environment familiarized by the members existing in the school. Hence, schools with positive climate will influence learning success (Cohen, 2006). Therefore, it is best to measure the relationship of school climate influencing language learning especially English Language. This is because anxiety in English language happens at all levels including at school and as stated by Hashemi (2011), language anxiety is a psychological construct that occurs due to intrinsic motivators such as selfperception from others, including peers, teachers, or interlocutors and beliefs about second language as well as insufficient command of the language. All these traits that happen in the school environment are the reasons to why school climate is a crucial variable in this scenario. Hence, in the Malaysian context, it is necessary to conduct an in-depth study regarding the extent to which school climate exudes influence on English Language Anxiety.

Apart from school climate, another factor that may induce anxiety is the teacher factor and the methods that they apply in class. This is because, considering that we are living in 21st century where technology has become a part of life and education, teachers must be well-equipped with knowledge about technological tools in order to apply productive and effective teaching methods in the classroom. Helen (2017), states that teachers require a wide range of competencies to face the 
complex challenges in today's globalised education systems. Teachers require a framework to guide them in combining the content knowledge that they have with knowledge of pedagogy and technology in enhancing their teaching. This framework should be applicable to any language teacher and the present study supports the use of the Technology Pedagogical Content Knowledge (TPACK) framework. In realization of the importance of this framework in English Language teaching within the Malaysian school context or environment, it is necessary to study the ability of language teachers to combine their knowledge of the subject matter, pedagogy and technology in their lesson as well as their teaching methods.

In light of this analysis, it is also necessary to study the extent to which school climate and Technology Pedagogical Content Knowledge (TPACK) influences English Language Anxiety. In the past there has not been much research exploring these two main factors affecting English Language Anxiety; even though there is an abundance in researches on English Language Anxiety regarding genders, motivation, coping strategies, age, level of anxiety and types of anxiety. Thus, the present research intends to bridge the gap in knowledge by exploring the correlation between school climate and Technology Pedagogical Content Knowledge (TPACK) in affecting English Language Anxiety. Hence, the objectives of the current research are presented as below:

1. To identify the level of English Language Anxiety faced by form 4 students in selected schools in Shah Alam

2. To determine the most influencing type of English Language Anxiety among Form 4 students in selected schools in Shah Alam

3. To examine the most significant factors in relation to School Climate (Physical Dimensions, Social Dimensions, Academic Dimensions) that affects English Language Anxiety

4. To examine the most significance factors of the teacher's teaching competencies that affect English Language Anxiety

With regards to the objectives above, the present study will be guided by the following conceptual framework 


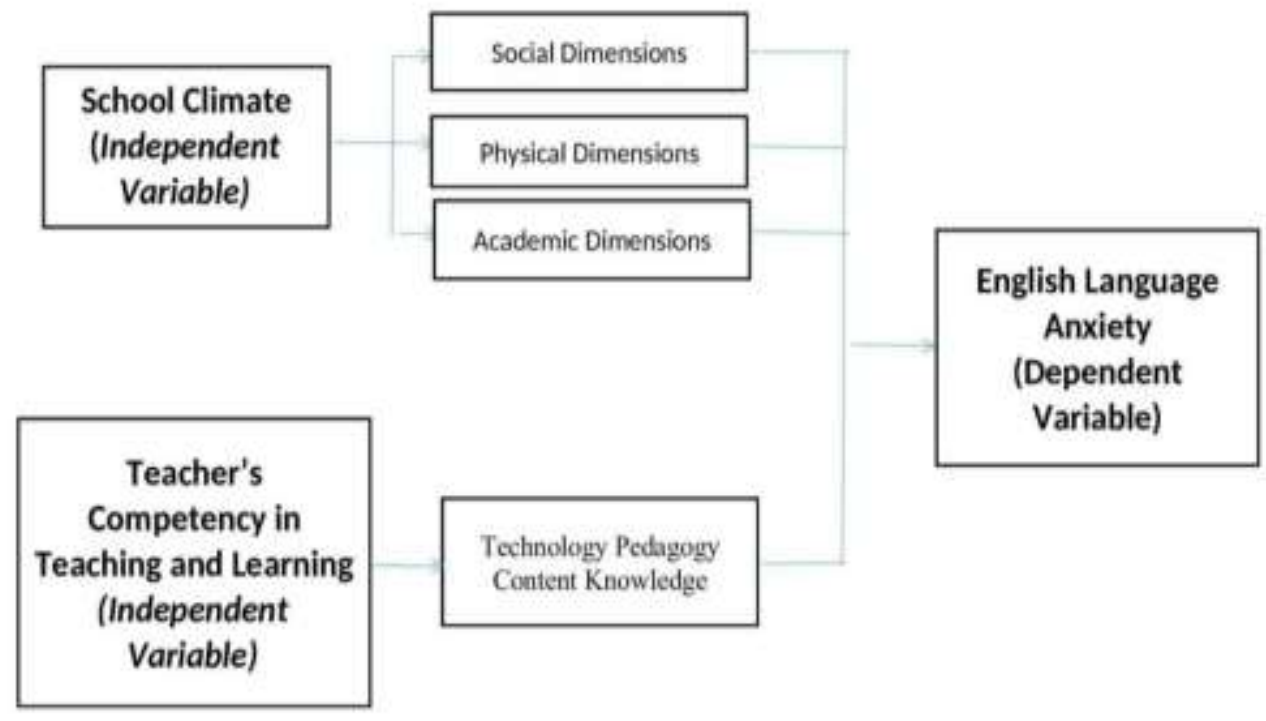

Fig. 2: Conceptual Framework

English Language Anxiety as the dependent variable needs to be studied with regards to the level of anxiety exuded and a second task would be identifying the most influencing type of anxiety in English Language Learning. School Climate as the independent variable consists of Social Dimensions, Physical Dimensions and Academic Dimensions. The present study undertakes the task of analysing the extent to which these dimensions are affecting English language Anxiety. Lastly, the study is also focused on analysing the teacher's competency in integrating technology, content and pedagogy and the significance of this competency in affecting English language anxiety.

\section{Methodology}

To begin with, the present study will be using quantitative data and the instruments are mainly the questionnaires. The research design that will be used in this study is a survey design and according to Creswell (2014), survey design is a method used in quantitative research whereby the researcher distributes a survey to a sample or to the entire population. The questionnaires proposed for the present are as follows:

- English Language Classroom Anxiety Scale (ELCAS) which was adapted from Foreign Language Classroom Anxiety Scale (FLCAS) and was created by Horwitz, Horwitz \& Cope (1986) The original questionnaire was renamed ELCAS since it is used to investigate English Language Anxiety. The same instrument was employed by Nur Afiqah (2015) and Zulkifli (2007) in their studies. The data obtained in this questionnaire will be used to determine the anxiety level of the respondents and to investigate the most dominant type of anxiety - between communication apprehension, test-anxiety or fear of negative evaluation.

- School climate as the variable affecting English language learning is studied in this research as well. The questionnaire known as School Climate English Language Anxiety (SCELA) scale was designed by the present researcher. The validity and reliability test of the questionnaire will be tested in a pilot study. The data derived from the second questionnaire will be used to 
establish the relationship between school climate and English language anxiety through linear regression.

- Teachers' competency in teaching, especially in integrating technology, pedagogy and content will be assessed in depth using the Technology Pedagogical Content Knowledge (TPACK) instrument developed by Mishra \& Koehler (2006) and Schmidt et al. (2009). The results from this questionnaire will be used to analyse the correlation between teacher's competency in teaching and learning and English Language Anxiety.

The sample population for this study are Form 4 students who will be selected randomly by their English teacher. The number of students selected will be based on Krejcie and Morgan's 1970 table of sample estimation. The reason for choosing Form 4 students is because they just recently took their PT3 examination and this may help to best reflect the factors affecting English language anxiety. This can help the researcher to find evidence if fear of evaluation could affect the level of anxiety. Also, Form 3 and Form 5 students are not encouraged to participate in this research as they will sit for PT3 and SPM examinations. Form 1 and Form 2 students are not to be encouraged to participate in this research as they may be experiencing difficulties settling down after the shift from primary school and this may skew the findings. The selected students as estimated will be 315 students will answer both ELCAS and SCELA. On the other hand, another group of respondents, who are the English teachers will also be selected based on Krejcie and Morgan's table. It is estimated that 30 English teachers will participate in the study. They will answer the TPACK questionnaire.

It is best to note that before the data collection will be carried out, a validity and reliability test will be conducted in order to establish the cronbach alpha. A content validity and face validity will be carried out among the panel experts that will be selected based on their teaching experience and the field of teaching. Also, a Content Value Index (CVI) and Kappa value will be calculated to eliminate any vague views about the items in the questionnaire. Along this side, a face validity will also be carried out as it can study the first impression about the questionnaire by the selected panel experts in this validity test.

\section{Conclusion}

It is hoped that this research will produce the data and results that will be helpful in identifying the most dominant types of anxiety influencing English Language learning and thus help to raise awareness regarding the level of anxiety and its effect among learners. This will allow teachers to produce new insights and find ways to overcome anxiety in English Language Learning. It is believed that school climate plays an important role in affecting English Language Anxiety whereby a positive climate could influence successful learning of the English Language. Besides that, teachers' competency in integrating technology, content and pedagogy may also play a role in language learning anxiety. It is because, $21^{\text {st }}$ century education is undergoing rapid changes from chalk and board to slides and videos, and this requires teachers to infuse technology in their teaching methods. Indeed, this progressively ubiquitous technology and widely available digital and networking tools has induced the potential for changes in the teaching and learning process. Hence, this research will be able to illuminate educators or course developers on how to build strategies to overcome English Language Anxiety fundamentally at the school level before learners continue their journey to tertiary education. To put in a brief point, this conceptual writing will be able to give the first insight about 
INTERNATIONAL JOURNAL OF ACADEMIC RESEARCH IN BUSINESS AND SOCIAL SCIENCES

Vol. 9, No. 13, Special Issue: Revolutionizing Education: Challenges, Innovation, Collaboration., 2019, E-ISSN: 2222-6990 @ 2019 HRMARS

the research that will be carried out to find the causal environments that lead to English Language Anxiety.

\section{Rreferences}

Alexandra, L. (2007). What Is School Climate?: Leadership Compass. Retrieved 5 April, 2018, from NAESP:

https://www.naesp.org/sites/default/files/resources/2/Leadership_Compass/2007/LC2007v 5n1a4.pdf

Alkhasawneh, F. (2016). Investigating Foreign Language Learning Anxiety: A Case of Saudi Undergraduate EFL Learners. Journal of Language and Linguistic Studies 12 (1), 137-148.

Alrabai, F. (2014). A Model of Foreign Language Anxiety in the Saudi EFL Context. English Language Teaching 7(7), 82-101.

Aydin, S., \& Zengin, B. (2008). Yabancı dil eğitiminde kaygı: bir literatür özeti. The Journal of Language and Linguistic Studies 4 (1), 81-94.

Aydın, S., Harputlu, L., Savranÿelika, I., Ultuk, ÿ., \& Genç, D. (2016). A Turkish Version of Foreign Language Anxiety Scale: Reliability and Validity. Procedia - Social and Behavioral Sciences 232, 250-256.

Brown, H. D. (2007). Principles of Language Learning and Teaching 5th Ed. New Jersey: Prentice-Hall.

Cohen, J. (2006). Social, Emotional, Ethical, and Academic Education: Creating A Climate for Learning, Participation in Democracy, and Well-Being. Harvard Educational Review, 201-237.

Cui, J. (2011). Research on High School Students' English Learning Anxiety. Journal of Language Teaching Res. 2(4), 875-880.

Frenzel, A., Pekrun, R., \& Goetz, T. (2007). Perceived Learning Environment and Students' Emotional Experiences: A Multilevel Analysis of Mathematics Classroom. Learning and Instruction 17, 456-460.

Hamid, M., \& Baldauf, J. (2013). Second Language Errors and Features of World Englishes. Retrieved from https://doi.org/10.1111/weng.12056.

Hashemi, M. (2011). Language Stress and Anxiety among the English Language Learners. ProcediaSocial and Behavioral Sciences 30, 1811-1816.

Horwitz, E. (2001). Language Anxiety and Achievement. Retrieved from Annual Rev. Applied Linguistics: http://dx.doi.org/10.1017/S02671905010000071

Horwitz, E., M. B, H., \& J, C. (1986). Foreign Language Classroom Anxiety. Modern Language Journal $70(2), 125-132$.

Hoy, W., John, T. C., Robert, B., \& Kottkamp. (1991). Open School/Health School: Measuring Organizational Climate. Sage Publications

.Hussein, G. (2010). The attitudes of undergraduate students towards motivation and technology in a foreign language classroom. International Journal of Learning and Teaching, 2(2)

Ilahi, B., AB, F., \& Habibullah, P. (2015). Investigating Foreign Language Learning Anxiety among Students Learning English in a Public Sector University, Pakistan. The Malaysian Online Journal of Educational Science, 27-37.

Jamilah, M. (2017). Anxiety in English Language Learning: A Case Study of English Language Learners in Saudi Arabia. English Language Teaching Vol 10 No 7. 
INTERNATIONAL JOURNAL OF ACADEMIC RESEARCH IN BUSINESS AND SOCIAL SCIENCES

Vol. 9, No. 13, Special Issue: Revolutionizing Education: Challenges, Innovation, Collaboration., 2019, E-ISSN: 2222-6990 @ 2019 HRMARS

Koehler, M. J., \& Mishra, P. (2008). Introducing TPACK in AACTE Committee on Innovation \& Technology (Eds.) . In Handbook of Technological Content Knowledge for Educators (pp. 3-29). New York: Routledge.

Kuperminc, G., Leadbeater, B., \& S. J, B. (2011). School Social Climate and Individual Differences in Vulnerability to Psychopathology among Middle School Students. Journal of School Health, 141-159.

Mary, M., Catherine, P., \& J. L, P. (2010). Student and Teacher Perceptions of School Climate: A Multilevel Exploration of Patterns of Discrepancy. Journal of School Health Vol 80 No 6.

Afiqah, N. A. L. (2015). A Study on Englush Language Anxiety among Adult Learners in Universiti Teknologi MARA (UiTM). Procedia- Social and Behavioral Sciences 208, 223-232.

Olga, N. (2012). The Competencies of Modern Teacher. Part 2: Pre-Service and In-Service Teacher Training (pp. 148-154). Bulgaria: 10th Annual Meeting of Bulgarian Comparative Education Society.

Oxford, R. (1999). Anxiety and The Language Learner: New Insights. In J. A. (Eds.), Affect in Language Learning (pp. 58-67). Cambridge: Cambridge University Press.

Sahin, I. (2011). Development of Survey of Technological Pedagogical Content Knowledge (TPACK). The Turkish Online Journal of Educational Technology, 97-105.

Schrum, L., Thompson, A., Maddux, C., Sprague, D., Bull, G., \& Bell, L. (2007). Research on the Effectiveness of Technology in Schools: The Roles of Pedagogy and Content. Contemporary Issues in Technology and Teacher Education 7(1), 456-460.

Snezana, K., Biljana, P., \& Dragana, K. (2012). Investigation of Motivation and Anxiety in Macedonia while Learning English as Second/Foreign Language. Procedia-Social and Behavioral Sciences 46, 3477-3481.

Soh Lan, L. (1994). Fluency and Accuracy in Spoken English: Implications for Classroom Practice in Bilingual Content. Retrieved 11 June, 2018, from The English Teacher XXIII: http://www.melta.org.my/ET/1994/main4.HTML

Toth, Z. (2011). Foreign Language Anxiety and Advanced EFL Learners: An Interview Study. WoPaLP Vol 5, 39-57.

Yazdanpanah, M., Sahragard, R., \& A, R. (2010). The Interplay of Locus of Control and Academic Achievement among Iranian English Foreign Language Learners. Crypiot Journal of Educational Sciences 5, 181-202.

Yvonne, J., \& K. S, G. (2013). Relationship between Anxiety, Attitude and Motivation of Tertiary Students in Learning English as a Second Language. Procedia - Social and Behavioral Science 90, 114-123.

Zucker, A., Tinker, R., Staudt, C., A, M., \& S, M. (2008). Learning Science in Grades 3-8 using Probeware and Computers: Findings from the TEEMSS II Project. Journal of Science Education and Technology Vol 17 No 1, 42-48.

Zulkifli, V. (2007). Language Classroom Anxiety: A Comparative Study of ESL Learners. Asian Journal of University Education, 3(2), 75-100. 